HELMINTHOLOGIA, 54, 3: 240 - 249, 2017

\title{
Helminth parasite communities of spotted rose snapper Lutjanus guttatus from the Mexican Pacific
}

\author{
F. N. MORALES-SERNA ${ }^{1,2}$, F. GARCÍA-VARGAS², R. M. MEDINA-GUERRERO², E. J. FAJER-ÁVILA ${ }^{2 *}$
}

${ }^{1}$ National Council of Science and Technology of Mexico (CONACyT), Mexico City, Mexico; ${ }^{2}$ Research Center for Food and Development (CIAD), Department of Aquaculture and Environmental Management, Mazatlán 82100, Sinaloa, Mexico, *E-mail: efajer@ciad.mx

Article info

Received February 1, 2017 Accepted April 19, 2017

\begin{abstract}
Summary
The helminth communities of $L$. guttatus from Mazatlan Bay (MB) and Banderas Bay (BB), on the Pacific coast of Mexico, were studied during two consecutive years. A total of 536 fish were collected and 19 parasite taxa registered (six digeneans, two cestodes, nine nematodes, and two monogeneans). Infection levels of common helminth species (Helicometrina nimia, Siphodera vinaledwardsii, Tetraphyllidea gen. sp., Pseudoterranova sp., Ancyrocephalidae gen. sp. and Microcotyloides incisa) as well as the infracommunity indices varied significantly between $M B$ and $B B$, and among dry and rainy seasons; however, no clear seasonal patterns were observed. Pseudoterranova larvae appeared frequently in $\mathrm{MB}$, possibly because of the presence of the California sea lion in this locality. Similarity analysis did not show a clear separation of parasite species composition between both localities, which suggest that fish samples came from a single population of $L$. guttatus.
\end{abstract}

Keywords: parasitic worms; fishery; marine ecology; Gulf of California

\section{Introduction}

Fishes of the family Lutjanidae, commonly known as snappers, are generally piscivores or planktivores distributed worldwide in tropical and subtropical waters. These fishes are targets of subsistence, commercial, and recreational fisheries. The spotted rose snapper Lutjanus guttatus inhabits coastal ecosystems, including reefs and estuaries, along the Eastern Pacific from Mexico to Peru. In Mexico, L. guttatus is one of the most economically important fish species, which has caused its exploitation above optimum levels (Amezcua et al., 2006). In addition, this fish is considered as one of the best candidates for commercial aquaculture in the region (Alvarez-Lajonchère et al., 2012; Hernández et al., 2016). As far as we are aware 16 species of helminths (Anisakis sp., Hamacredium lariosi, Helicometrina nimia, Lecithochirium microstomum, Maculifer japonicus, Microcotyloides incisa, Neobivagina aniversaria, Polycryptocylis leonilae, Polymicrocotyle manteri,
Pseudoterranova sp., Siphodera vinaledwardesii, Euryhaliotrema mehen, E. perezponcei, Haliotrematoides guttati, $H$. plectridium and $H$. spinatus) are known from $L$. guttatus (Lamothe-Argumedo et al., 1997; Pérez-Ponce de León et al., 1999; García-Vargas et al., 2008; Soler-Jímenez \& Fajer-Ávila, 2012; Soler-Jímenez et al., 2012). Given the importance of $L$. guttatus for fisheries and aquaculture, it is necessary to improve our knowledge about its parasite diversity and infection levels on wild fish populations. In fish parasite ecology, there has been some evidence for an increase in parasite diversity with host size (Lo et al., 1998); however, in many cases the correlation between those factors may be weak and non-significant (Poulin, 2000). Other ecological processes may occur at spatial scale. For instance, similarity in parasite communities may decay with increasing distance between localities which could be related to discontinuities in the landscape or the probability that parasites species disperse among localities via host movements (Poulin, 2003; Timi et al., 2010). Such variation

\footnotetext{
* - corresponding author
} 
in composition and abundance of parasites provides information about the host population movements and structure which can be useful for the efficient and sustainable management of a commercially exploited marine fish species (MacKenzie, 2005; Moore et al., 2011; Baldwin et al., 2012); however, this biological tool has received limited use in Mexican fisheries (Violante-González et al., 2016).

Therefore, the aim of this study was 2-fold: (1) to analyse the temporal and spatial variation of fish parasite populations and infracommunities of $L$. guttatus from two important fishing localities in the Mexican Pacific; and (2) to evaluate the relationship between parasite load and fish body length. This information may be useful for strategies of management and protection of local fishery resources.

\section{Materials and Methods}

A total of 536 specimens of $L$. guttatus were collected between April 2004 and February 2006 from two important fishing localities in the Mexican Pacific: Mazatlan Bay (MB, $23^{\circ} 12^{\prime} \mathrm{N}, 106^{\circ} 26^{\prime} \mathrm{W}$ ) and Banderas Bay (BB, $20^{\circ} 44^{\prime} \mathrm{N}, 105^{\circ} 26^{\prime} \mathrm{W}$ ) which are approximately $300 \mathrm{~km}$ apart. The study area experiences two contrasting seasons, dry from December to May, and rainy from June to November. Thus, we performed comparisons of parasitological data between localities, and among climatic seasons (dry 2004, rainy 2004 , dry 2005, rainy 2005, and dry 2006).

Each fish was measured for standard length $(\mathrm{cm})$ and a complete necropsy was done with the aid of a dissection microscope. The fish length was compared between both localities with Mann-Whitney test with SigmaStat 3.5 software. All helminths collected were counted and processed according to Lamothe-Argumedo (1997). For each season and locality, prevalence and mean intensity (sensu Bush et al., 1997) with their respective $95 \%$ confidence interval were calculated for each parasite species or taxon identified using Quantitative Parasitology on the Web (QPweb) software (Rozsa et al., 2000; Reiczigel et al., 2013). This software was also used to compare prevalence and mean intensity of the commonest species (prevalence $>10 \%$ ) among all samples. Specifically, prevalence was compared using Fisher's exact test and intensity using Mood's median test. A posteriori pairwise comparisons of prevalence and intensity were performed, respectively, with Fisher's exact test and bootstrap $t$-test with 1,000 replications.

Analyses were made at the infracommunity (all the helminth parasites in an individual fish) level (Bush et al., 1997) using the num-

Table 1. Overall prevalence (P), mean intensity (MI) and infection site of helminth parasites in Lutjanus guttatus from two localities in the Mexican Pacific. Values in parentheses are $95 \%$ confidence intervals.

\begin{tabular}{|c|c|c|c|c|c|}
\hline \multirow[b]{3}{*}{ Parasite } & \multirow[b]{3}{*}{ Infection site } & \multicolumn{4}{|c|}{ Locality } \\
\hline & & \multicolumn{2}{|c|}{ Mazatlan Bay $(n=283)$} & \multicolumn{2}{|c|}{ Banderas Bay $(n=253)$} \\
\hline & & $\mathrm{P} \%$ & $\mathrm{Ml}$ & $\mathrm{P} \%$ & $\mathrm{Ml}$ \\
\hline \multicolumn{6}{|l|}{ Digenea } \\
\hline Stephanostomun casum (A) & Intestine and stomach & $1.1(0.2-3.1)$ & 1 & $1.2(0.2-3.4)$ & 1 \\
\hline Hamacreadium mutabile (A) & Intestine and stomach & $6.4(3.8-9.9)$ & $1.9(1.3-2.8)$ & $0.4(0-2.2)$ & 13 \\
\hline Helicometrina nimia (A) & Intestine and stomach & $2.8(1.2-5.5)$ & $2.6(1.2-5)$ & $42.3(3.6-48.6)$ & $4.6(3.7-6.3)$ \\
\hline Siphodera vinaledwardsii (A) & Intestine and stomach & $0.4(0.0-2.0)$ & 3 & $36.8(30.8-43)$ & $6(4.6-8.2)$ \\
\hline Torticaecum sp. (L) & Gills & $1.4(0.4-3.6)$ & $1.2(1-1.5)$ & 0.0 & 0.0 \\
\hline Parahemiurus merus (A) & Intestine and stomach & $0.7(0.1-2.5)$ & $1.5(1-1.5)$ & $0.8(0.1-2.8)$ & $2(1-2)$ \\
\hline \multicolumn{6}{|l|}{ Cestoda } \\
\hline Trypanorhyncha (L) & Intestinal lumen & $0.4(0.0-2)$ & 1 & 0.0 & 0.0 \\
\hline Tetraphyllidea (L) & Intestinal wall and stomach & $36.4(30.8-42.3)$ & $18.3(11.4-39.9)$ & $29.6(24.1-35.7)$ & $157(72.3-426)$ \\
\hline \multicolumn{6}{|l|}{ Nematoda } \\
\hline Capillariidae (A) & Intestine and stomach & $1.1(0.2-3.1)$ & 1 & $1.6(0.4-4)$ & 1 \\
\hline Anisakis sp. (L) & Mesenteries & $0.7(0.1-2.5)$ & 1 & $1.6(0.4-4)$ & $1.5(1-2)$ \\
\hline Pseudoterranova sp. (L) & $\begin{array}{l}\text { Mesenteries, liver, intestinal } \\
\text { wall and stomach }\end{array}$ & $42.8(36.9-48.7)$ & $5.2(4.3-6.5)$ & $2.4(0.9-5.1)$ & $1.2(1-1.5)$ \\
\hline Hysterothylacium sp. (L) & $\begin{array}{l}\text { Mesenteries and intestinal } \\
\text { lumen }\end{array}$ & 0.0 & 0.0 & $9.9(6.5-14.2)$ & $2.2(1.5-3.3)$ \\
\hline Goezia sp. (L) & Intestine and stomach & $1.8(0.6-4.1)$ & $2.4(1-3.2)$ & $1.2(0.2-3.4)$ & $4.3(1-6.7)$ \\
\hline Ascarophis sp. (A) & Stomach & $5.3(3.0-8.6)$ & $1.9(1.1-3.4)$ & $1.2(0.2-3.4)$ & 1 \\
\hline Spinitectus sp. (L) & Intestinal lumen & 0.0 & 0.0 & $0.8(0.1-2.8)$ & $1.5(1-1.5)$ \\
\hline Procamallanus (Spirocamallanus) sp. (L) & Intestine and stomach & $2.5(1.0-5.0)$ & $1.3(1-1.9)$ & $0.8(0.1-2.8)$ & $5.5(1-5.5)$ \\
\hline Philometra sp. (A) & Gonads & $1.1(0.2-3.1)$ & $1.3(1-1.7)$ & $1.6(0.4-4)$ & $1.2(1-1.5)$ \\
\hline \multicolumn{6}{|l|}{ Monogenea } \\
\hline Ancyrocephalidae & Gills & $80.6(75.5-85.0)$ & $68(55.2-82.8)$ & $92.5(88.5-95.4)$ & $53.4(47-61.6)$ \\
\hline Microcotyloides incisa & Gills & $10.2(7-14.4)$ & $2.1(1.6-3.2)$ & $34(28.2-40.2)$ & $3.1(2.5-4.4)$ \\
\hline
\end{tabular}

$A=$ adult; $L=$ larvae 
ber of species $(\mathrm{S})$, number of individuals $(\mathrm{N})$, Brillouin's index of diversity $(\mathrm{HB})$ and Berger-Parker's index of dominance (BP) (Magurran, 1988). Mann-Whitney and Kruskal-Wallis tests were used to determine, respectively, significant differences in infracommunity indices between localities (MB and $\mathrm{BB}$ ) and between climatic seasons. Possible significant correlation between infracommunity indices and fish body length were detected with Spearman's rank test. Only correlations of $r>0.4$ were considered significant. Uninfected fish were excluded from analyses at the infracommunity level, except for correlation analyses.

A non-metric multidimensional scaling (MDS) plot was performed to analyse differences in the composition of helminth infracommunities between MB and BB. The magnitude of such differences was tested with a one-way analysis of similarity (ANOSIM). Similarity percentages (SIMPER) were calculated to identify the helminth parasite species driving the differences between communities at different localities. These multivariate analyses were performed in PRIMER v6 (Clarke \& Warwick, 2001; Clarke \& Gorley, 2006) based on standardised abundance data and Bray-Curtis distances.

\section{Results}

Fish body length (mean \pm standard deviation) from BB $(24.7 \pm$ $5.8 \mathrm{~cm}$ ) was significantly larger than that from MB $(20.8 \pm 4.3 \mathrm{~cm})$ when data from all seasons were pooled $(U=19528.0, P<0.001)$. In the total sample $(n=536)$, 19 helminth species (six digeneans, two cestodes, nine nematodes, and two monogeneans) were found (Table 1). Of these, 15 were present in both localities and only six (Helicometrina nimia, Siphodera vinaledwardsii, Tetraphyllidea gen. sp., Pseudoterranova sp., Ancyrocephalidae gen. sp., and Microcotyloides incisa) can be considered the commonest as they reached prevalences $>10 \%$ in fish from one or both localities. The monogenean Ancyrocephalidae gen. sp. was by far the dominant species. This species as well as Helicometrina nimia, $S$. vinaledwardsii, and $M$. incisa were significantly more prevalent in $\mathrm{BB}$ than in $\mathrm{MB}$ (all $P<0.0001$ ) but their intensity did not vary between both localities (all $P>0.05$ ). For Tetraphyllidea gen. sp. there were not differences in prevalence and intensity between both localities $(P>0.05)$ while Pseudoterranova sp. showed significantly higher prevalence $(P<0.0001)$ and intensity $(P<0.05)$ in $\mathrm{MB}$ than in $\mathrm{BB}$.

In each locality, the helminth species showed an unequal distribution between climatic seasons (Tables 2 and 3), which was confirmed by significant differences in prevalence and intensity of the commonest species $(P<0.05)$. However, no clear seasonal patterns could be detected according to the posteriori pairwise comparisons (data not shown).

Considering pooled samples from each locality, all infracommunity indices were significantly higher in $\mathrm{BB}$ than in $\mathrm{MB}(\mathrm{S}: \mathrm{U}=23845.5$, $P<0.001 ; \mathrm{N}: \mathrm{U}=25396, P<0.001 ; \mathrm{HB}: \mathrm{U}=27013.5, P<0.001$; BP: $U=26199, P=0.001$ ) (Fig. 1). In each locality, all infracommunity indices varied significantly between dry and rainy seasons
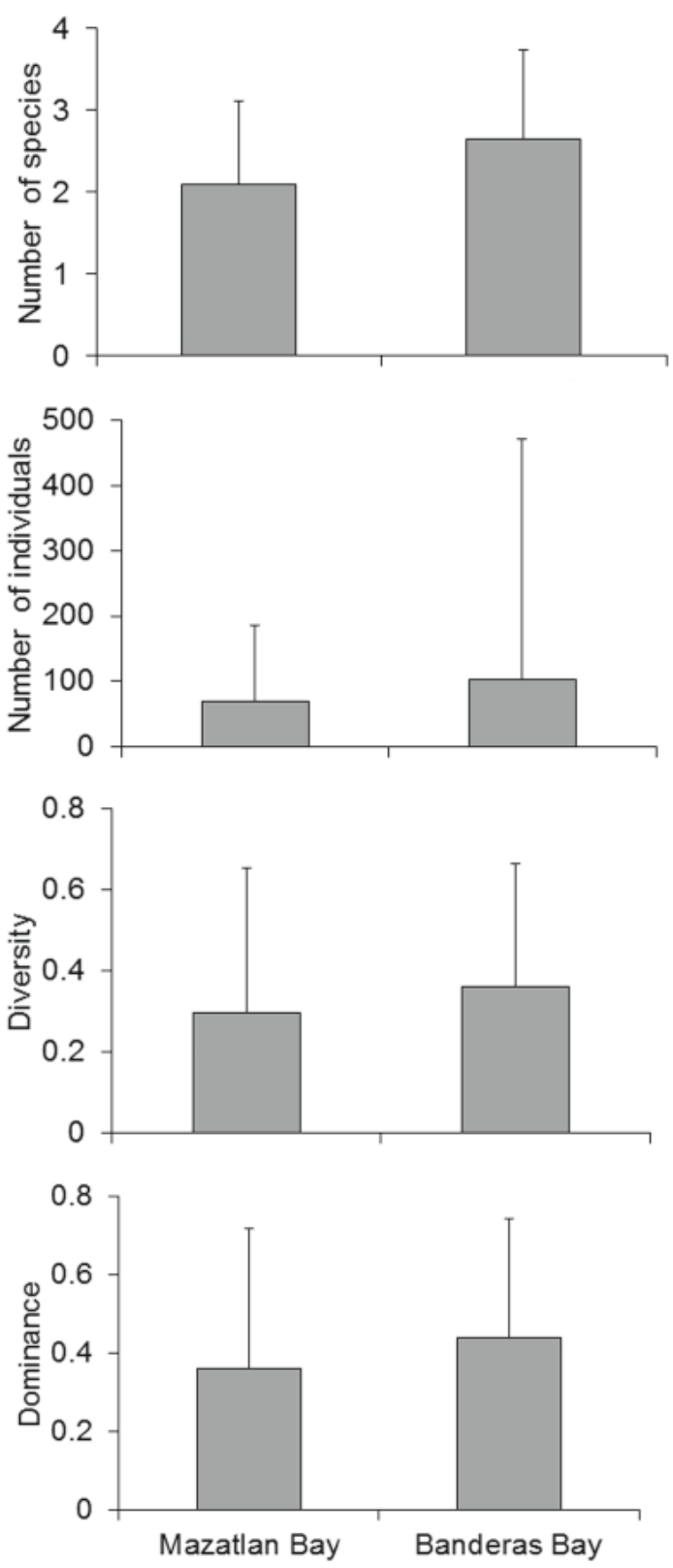

Fig. 1. Overall mean infracommunity descriptors \pm standard deviation of Lutjanus guttatus collected in Mazatlan Bay and Banderas Bay.

$(P<0.05)$; however, no clear seasonal patterns could be detected (Fig. 2). There was no significant correlation between infracommunity indices and fish body length, neither when samples were pooled nor when analysed separately.

Multidimensional scaling (Fig. 3) and global ANOSIM (Global $R$ $=0.042, P=0.01$ ) showed little but significant separation of parasite species composition between both localities. SIMPER was low in MB (55) and BB (61) with Ancyrocephalidae gen. sp. being the main responsible (>90\%) to similarity within samples of each locality. Average dissimilarity (44) between MB and BB was also 


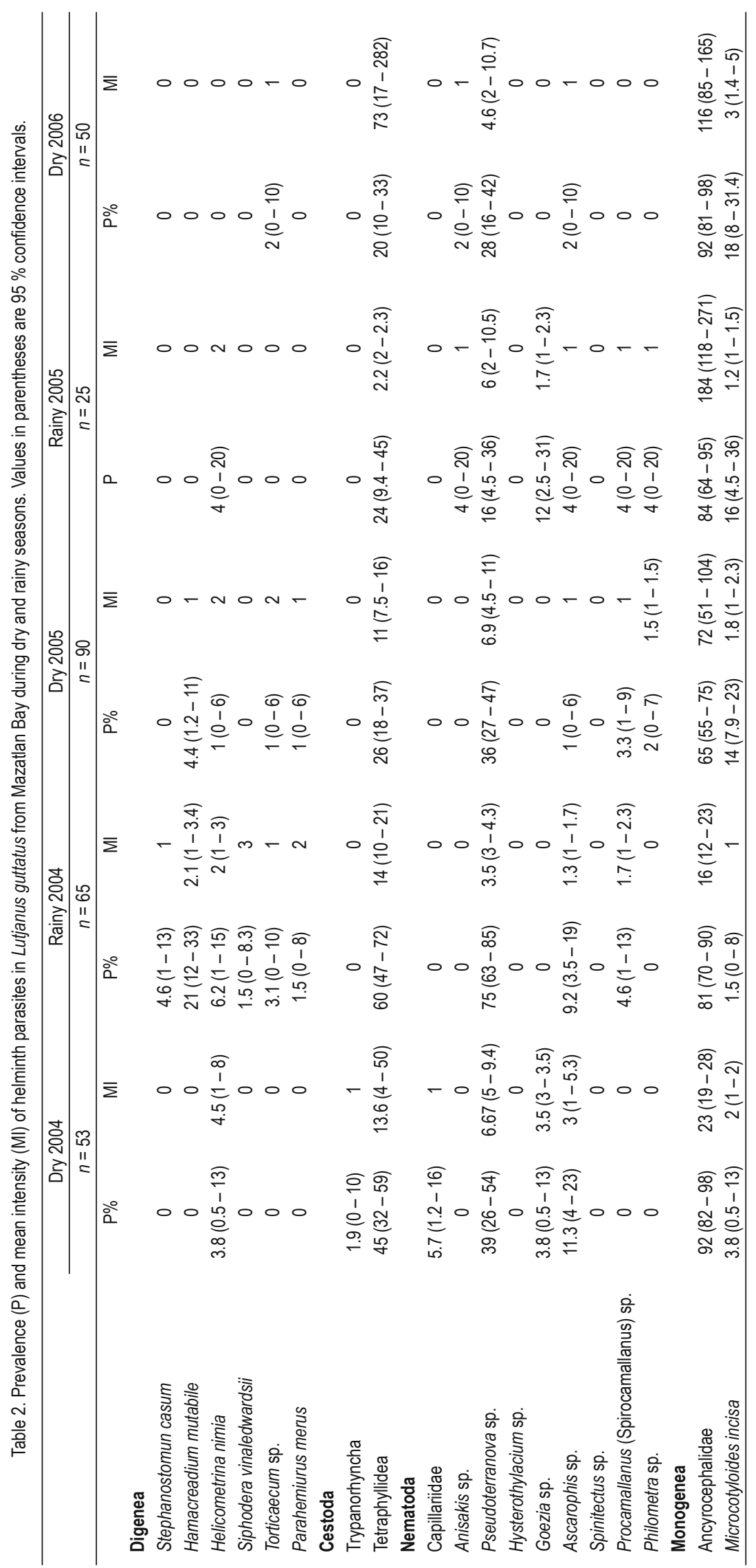


Mazatlan Bay
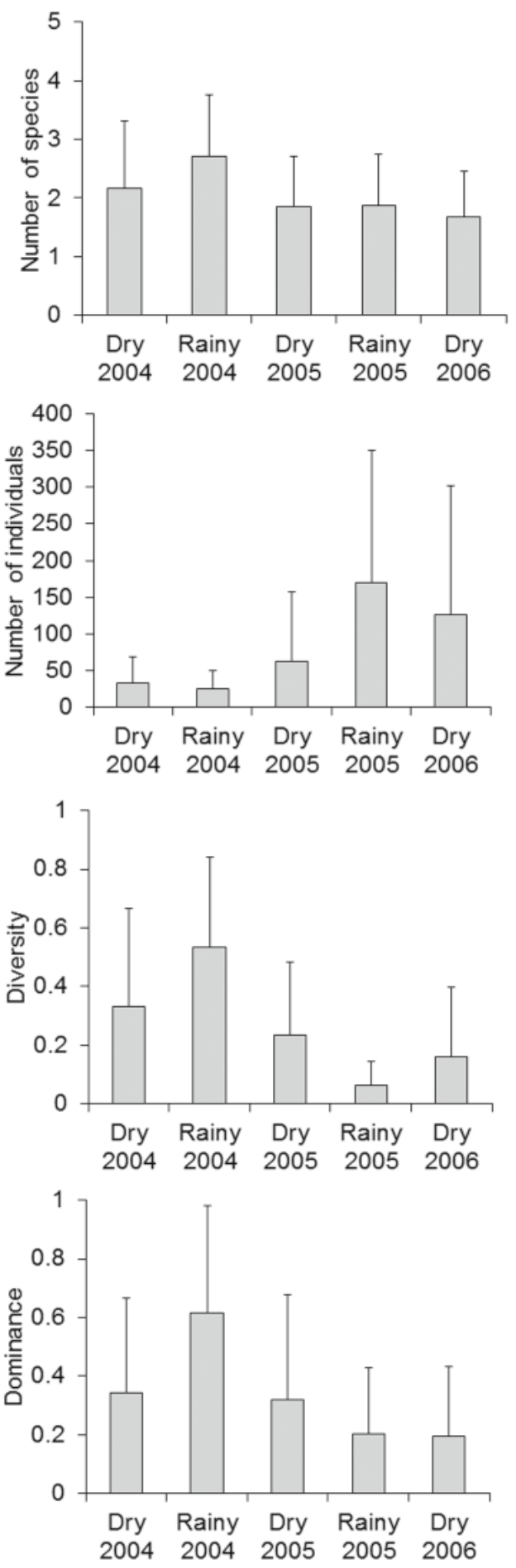

Banderas Bay
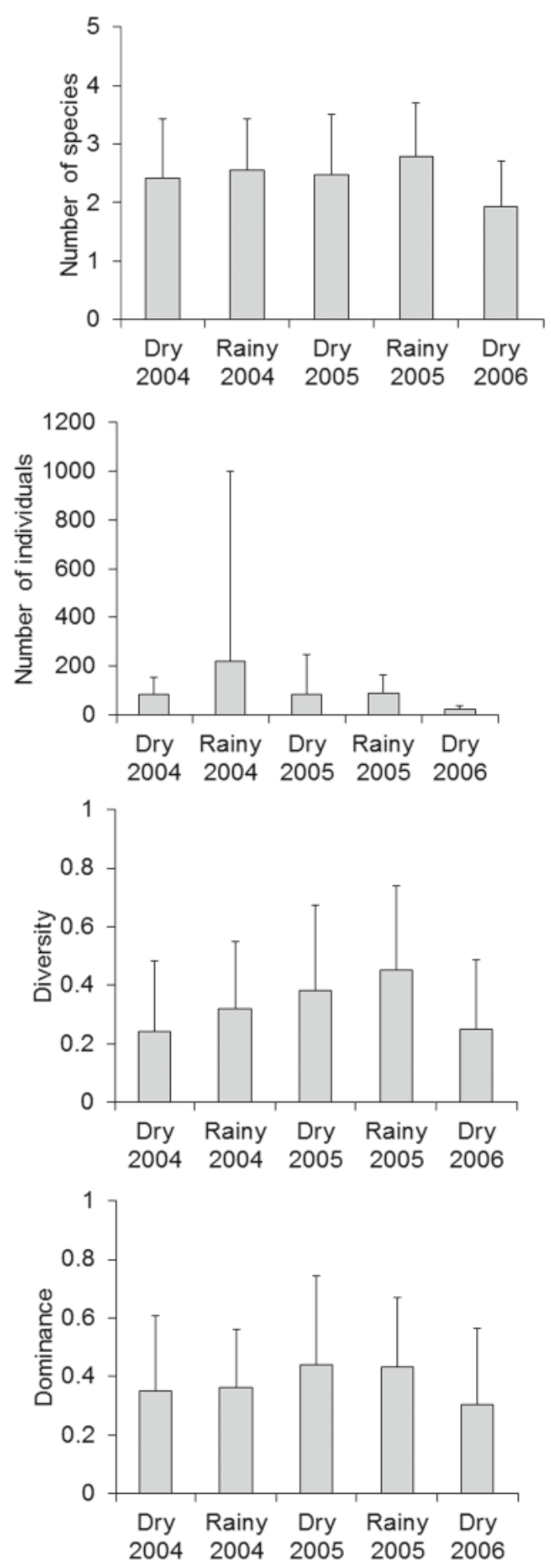

Fig. 2. Mean infracommunity descriptors \pm standard deviation of Lutjanus guttatus in each sampling season in Mazatlan Bay and Banderas Bay. 


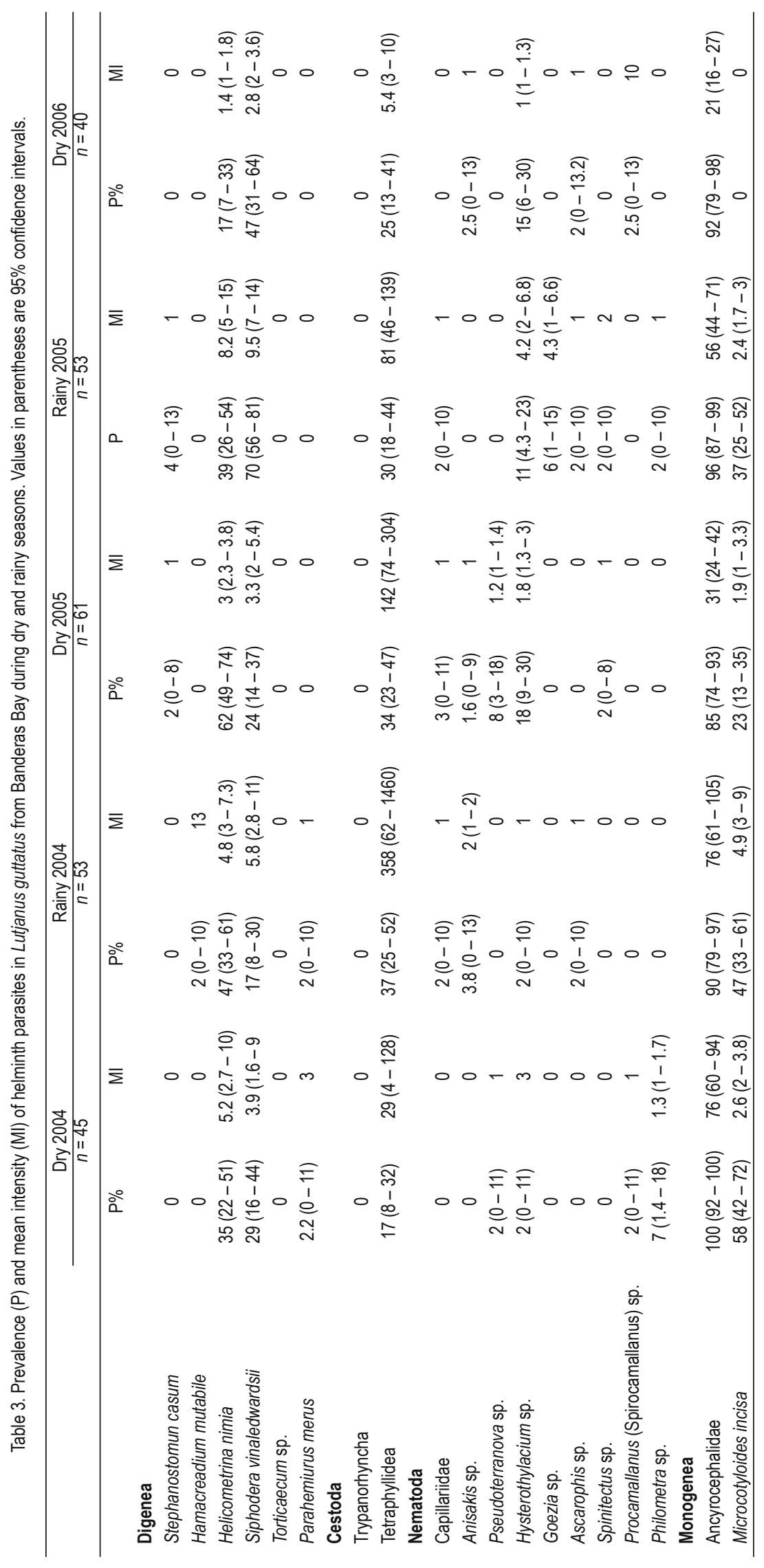




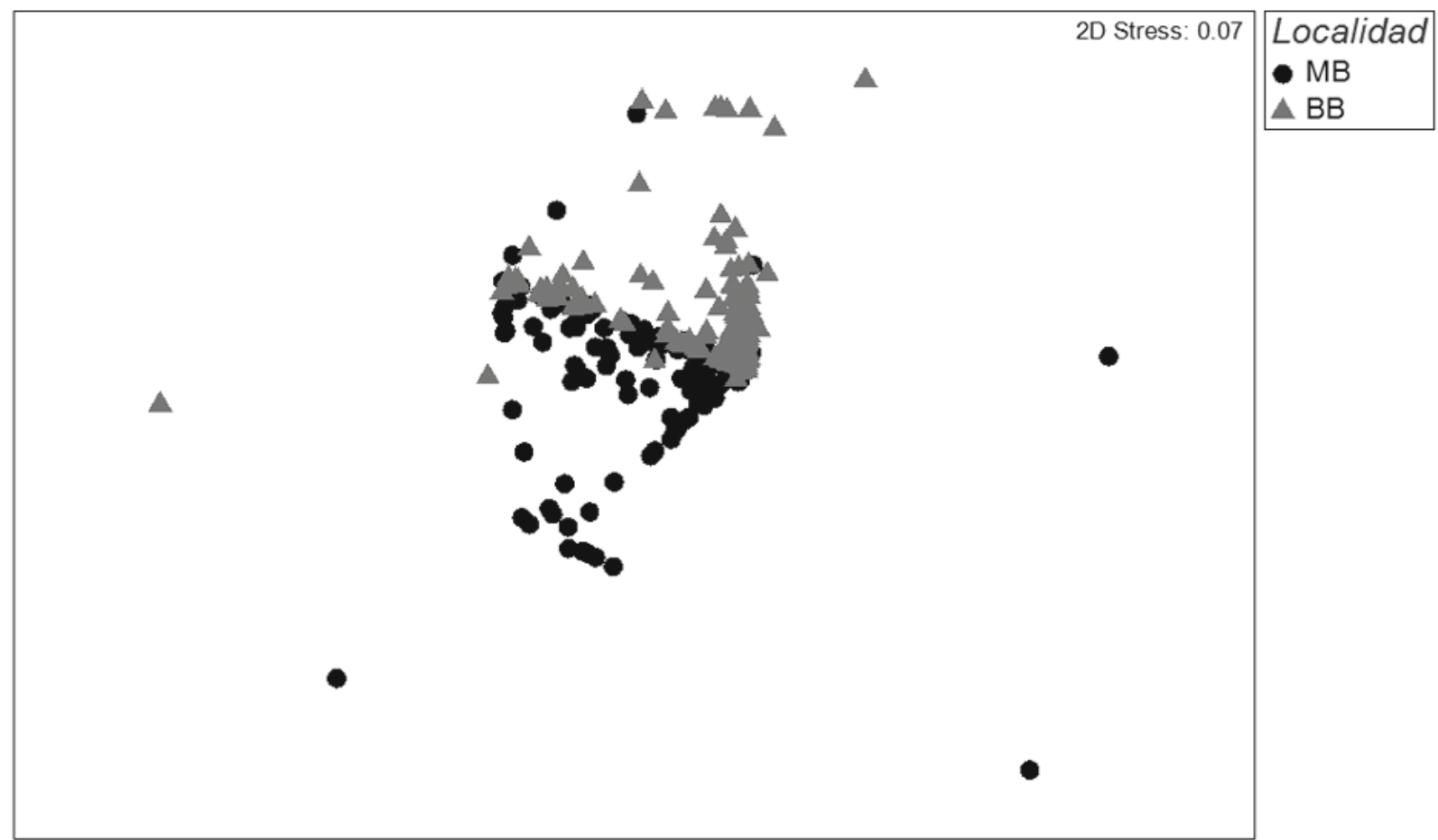

Fig. 3. Two-dimensional nonmetric MDS plot of Bray-Curtis similarity based on standardised abundance data of helminth parasites communities of Lutjanus guttatus collected periodically over 2 years in Mazatlan Bay (MB) and Banderas Bay (BB).

attributed to Ancyrocephalidae gen. sp. followed by Tetraphyllidea gen. sp. and Pseudoterranova sp. (Table 4).

\section{Discussion}

The 19 helminth species of $L$. guttatus herein reported contrast with the five helminth species found in Caulolatilus princeps, nine in Sebastes miniatus, and 14 in Caranx caballus from the Mexican Pacific (Rodríguez-Santiago \& Rosales-Casián, 2011; Rodríguez-Santiago et al., 2014; Violante-González et al., 2016). Possibly, such differences would be indicating a more varied diet in L. guttatus. Nonetheless, several parasite species are accidental.
Our results showed a wide dominance of ancyrocephalids, followed by Tetraphyllidea. Unfortunately, at the time this survey was realized, species of ancyrocephalids were not correctly discriminated and quantified. Nowadays, based on additional studies, we know that $L$. guttatus serves as host to five ancyrocephalids species (Euryhaliotrema mehen, E. perezponcei, Haliotrematoides guttati, $H$. plectridium and $H$. spinatus), of which $E$. perezponcei has been the most frequent and abundant species on either wild or sea-caged fish (Soler-Jímenez \& Fajer-Ávila, 2012; Soler-Jímenez et al., 2015). Similarly, Montoya-Mendoza et al. (2014, 2016) identified 21 and 25 helminth species from Lutjanus campechanus and L. synagris, respectively, from the southern Gulf of Mexico,

Table 4. SIMPER analysis for helminth parasites of Lutjanus guttatus from Mazatlan Bay and Banderas Bay.

\begin{tabular}{lcccccc}
\hline & Mazatlan & Banderas & & & & \\
\cline { 2 - 4 } Parasite & AA & AA & AD & D/SD & $\%$ & C \% \\
\hline Ancyrocephalidae & 68.94 & 73.22 & 17.83 & 1.11 & 40.29 & 40.29 \\
Tetraphyllidae & 13.68 & 11.86 & 10.49 & 0.72 & 23.69 & 63.98 \\
Pseudoterranova sp. & 12.43 & 0.07 & 6.23 & 0.52 & 14.07 & 78.05 \\
Helicometrina nimia & 0.40 & 5.39 & 2.83 & 0.42 & 6.39 & 84.44 \\
Siphodera vinaledwardsii & 0.04 & 4.71 & 2.36 & 0.44 & 5.34 & 89.78 \\
Microcotyloides incisa & 1.07 & 2.13 & 1.51 & 0.31 & 3.40 & 93.18 \\
\hline
\end{tabular}

$\mathrm{AA}$ average abundance; $\mathrm{AD}$ average dissimilarity; $\mathrm{D} / \mathrm{SD}$ dissimilarity/standard deviation; \% and $\mathrm{C} \%$ respectively percentage of total and cumulative dissimilarity contributed by each parasite species 
with ancyrocephalids (Euryhaliotrema tubocirrus and Haliotrematoides cornigerum) being the most prevalent parasites, followed by Tetraphyllidea. These findings fit with the idea that snappers are highly suitable host for ancyrocephalids worldwide (Kritsky, 2012). The tetraphyllid life cycle is poorly known (Jensen \& Bullard, 2010), but at least three hosts are involved: copepods, euphausiid shrimps or occasionally a pelecypod mollusk as first intermediate hosts; teleost fishes, decapods or cephalopods as second intermediate hosts; and elasmobranchs as definitive hosts (Caira \& Reyda, 2005). In this study, the higher prevalence and abundance of tetraphyllid larvae with respect to other helminths could be associated to the feeding habits of $L$. guttatus. This fish is an active predator and opportunistic carnivorous with a diet composed mostly of crustaceans, fish and mollusks (Rojas-Herrera et al., 2003), which together with potential elasmobranchs hosts are well represented in the sampling areas (van der Heiden \& Hendrickx, 1982; Espinosa-Pérez et al., 2004; Hendrickx et al., 2005).

In MB, Pseudoterranova larvae appeared in all sampling months with relatively high prevalence and intensity. In contrast, this parasite was almost absent in BB. Pseudoterranova nematodes adults are common parasites of marine mammals. We suppose that the occurrence of Pseudoterranova larvae in $L$. guttatus from MB is associated to the presence of the California sea lion (Zalophus californianus) that may serve as final host. The main rookeries of Z. californianus are distributed from California islands to Baja California and the Gulf of California, with the southernmost rest rookery located in MB (Hoyos-Padilla \& Gallo-Reynoso, 2015). This pinniped feed on a variety of fish species and its diet may vary among rookeries within the Gulf of California (García-Rodríguez \& Aurioles-Gamboa, 2004); however, its feeding habits in MB are unknown. Our study suggests that $L$. guttatus forms part of $Z$. californianus diet.

In this study, the lack of association between fish length and parasite load suggests that other local ecological factors may be more influential in regulating the parasite community of $L$. guttatus. It could be a biased analysis since our sampling effort just comprised a portion of the entire range of fish length. Nonetheless, a meta-analysis performed by Poulin (2000) indicated that the overall, mean correlation between fish length and intensity of infection, weighted for sample size, was not significantly different from zero, independent of mode of infection.

In the overall samples, metrics of most component species and infracommunities were higher in BB than in MB. Given that helminths usually have indirect life cycles that require a variety of invertebrate and vertebrate hosts, a community of these parasites within a host organism reflects the presence in the ecosystem of any other organism involved in the various parasite life cycles (Marcogliese, 2005). Thus, it is possible that the relatively low diversity of helminths in $\mathrm{MB}$ is a result of the absence of some intermediate or final hosts.

Despite the economic importance of $L$. guttatus, its stock structure along the Mexican Pacific remains unknown. Recently, García-
Vásquez et al. (2015), based on the molecular similarity between individuals of $E$. perezponcei from two distant localities (MB and Chamela Bay), suggested that populations of $L$. guttatus move along the Pacific coast of Mexico. Molecular markers may be used for population structure analysis in parasites and hosts. However, it is possible that the sole examination of organisms at genetic level is not sufficient to discriminate fish stocks. In the present study, there were not notable differences of parasite communities between MB and BB, which could suggest that specimens of $L$. guttatus caught in those localities belong to the same fish population. It was confirmed by the Global $R$ from ANOSIM which was close to 0 , indicating that differences in parasite species composition between both sites were small. As mentioned earlier, ancyrocephalids dominated largely the samples in terms of prevalence and intensity of infection. Also, these monogeneans were the main responsible of dissimilarity between both localities. Grutter (1998) argued that monogeneans may be useful as biological tags, since they do not leave their host, differences in abundance of these parasites between localities would be indicating different fish stocks. On other hand, Lester and MacKenzie (2009) pointed out that monogeneans seem to be short-lived, surviving on fish for less than a year, which make them of little value for stock discrimination since fish acquire and lose these parasites during their geographic move.

In conclusion, L. guttatus harbored helminth parasite communities which showed stability over space but no over time in terms of composition and infection levels. We consider that our data analyses provide some evidence to claim that fish samples came from a single population of $L$. guttatus.

\section{Acknowledgements}

We thank to the Centro Regional de Investigación Pesquera (CRIP) located in Banderas Bay for their hospitality during the field work. Edgardo López Valerio helped with data analysis. FGV was supported through funding from a PhD scholarship from the National Research Council of Mexico (CONACYT). This study was supported by the grant No. 2003-02-073 from the Secretaría de Agricultura, Ganadería, Desarrollo Rural, Pesca y Alimentación (SAGARPA) and CONACYT.

\section{References}

Alvarez-Lajonchère, L., Abdo De La Parra, M.I., Rodríguez-lbarra, L.E., Velasco-Blanco, G., Puello-Cruz, A.C., González-Rodríguez, B., Ibarra-Soto, A., Ibarra-Castro, L. (2012): The scale-up of spotted rose snapper, Lutjanus guttatus, larval rearing at Mazatlan, Mexico. J. World Aquacult. Soc., 43: 411 - 422. DOI: 10.1111/j.1749-7345.2012.00573.x

Amezcua, F., Soto-Avila, C., Green-Ruiz, Y. (2006): Age, growth, and mortality of the spotted rose snapper Lutjanus guttatus from the southeastern Gulf of California. Fish. Res., 77: 293 - 300. DOI: 
10.1016/j.fishres.2005.10.012

BALDWIN, R.E., BANKS, M.A., JACOBSON, K.C. (2012): Integrating fish and parasite data as holistic solution for identifying the elusive stock structure of Pacific sardines (Sardinops sagax). Rev. Fish Biol. Fish., 22: 137 - 156. DOI: 10.1007/s11160-011-9227-5 Bush, A.O., LAfFerty, K.D., Lotz, J.M., Shostak, A.W. (1997): Parasitology meets ecology on its own terms: Margolis et al. revisited. J. Parasitol., 83: 575 - 583. DOI: 10.2307/3284227

CaIRA, J.N., Reyda, F.B. (2005): Eucestoda (true tapeworms). In: Rohde, K. (Ed.) Marine Parasitology. Collingwood, Australia: CSIRO Publishing, pp. $92-104$

CLARKE, K.R., GoRley R.N. (2006): PRIMER v6: user manual/tutorial. PRIMER-E, Plymouth, UK, 190 pp.

CLARKE, K.R., WARWICK, R.M. (2001): Change in marine communities: an approach to statistical analysis and interpretation. 2nd edn. PRIMER-E, Plymouth

Espinosa-Pérez, H., Castro-Aguirre, J.L., Huidobro-Campos, L. (2004): [Faunistic list of Mexico. Part IX, Systematic catalogue of sharks (Elasmobranchii: Selachimorpha)]. Mexico City, Universidad Nacional Autónoma de México, Instituto de Biología, 133 pp. (In Spanish)

Garcia-Rodríguez, F.J., Aurioles-Gamboa, D. (2004): Spatial and temporal variation in the diet of the California sea lion (Zalophus californianus) in the Gulf of California, Mexico. Fish. Bull., 102: $47-62$

García-Vargas, F., Fajer-Ávila, E., Lamothe-Argumedo, R. (2008): Two new species of Dactylogyridae (Monogenoidea) on rose spotted snapper, Lutjanus guttatus (Osteichthyes: Lutjanidae), from the coast of Nayarit and Sinaloa, Mexico. Zootaxa, 1729: 61 - 68 García-Vásquez, A., Pinacho-Pinacho, C.D., Soler-Jiménez, L.C., Fajer-Ávila, E.J., Pérez-Ponce De León G. (2015): Haliotrematoides spp. (Monogenea: Dactylogyridae) parasitizing Lutjanus guttatus (Lutjanidae) in two localities of the Pacific coast of Mexico, and their phylogenetic position within the Ancyrocephalinae through sequences of the 28S rRNA. Rev. Mex. Biodiv., 86: 298 - 305. DOI: 10.1016/j.rmb.2015.04.027

GRUTTER, A.S. (1998): Habitat-related differences in the abundance of parasites from a coral reef fish: an indication of the movement patterns of Hemigymnus melapterus. J. Fish Biol., 53: 49 - 57. DOI: 10.1111/j.1095-8649.1998.tb00108.x

HendrickX, M.E., Brusca, R.C., FindLey, L.T. (2005): [List and distribution of the macrofauna from the Gulf of California, Mexico. Part I, Invertebrates]. Tucson, Arizona-Sonora Museum, 429 pp. (In Spanish)

Hernández, C.H., Hernández, C., Martínez-Cordero, F.J., Castañeda-Lomas, N., Rodríguez-Domínguez, G., Tacon, A.G.J., Aragón-NorIEGA, E.A. (2016): Effect of density at harvest on the growth performance and profitability of hatchery-reared spotted rose snapper, Lutjanus guttatus, cultured in floating net cages. J. World Aquacult. Soc., 47: 51 - 60. DOI: 10.1111/jwas.12253

Hoyos-Padilla, E.M., Gallo-Reynoso, J.P. (2015): Occasional presence of a California sea lion (Zalophus californianus) at Isla Roca
Partida, Revillagigedo Archipielago, México. Therya, 6: 489 - 494. Jensen, K., Bullard, S.A. (2010): Characterization of a diversity of tetraphyllidean and rhinebothriidean cestode larval types, with comments on host associations and life-cycles. Int. J. Parasitol., 40: 889 - 910. DOI: 10.1016/j.jpara.2009.11.015

KRISKY, D.C. (2012): Dactylogyrids (Monogenoidea: Polyonchoinea) parasitizing the gills of snappers (Perciformes: Lutjanidae): revision of Euryhaliotrema with new and previously described species from the Red Sea, Persian Gulf, the eastern and Indo-west Pacific Ocean, and the Gulf of Mexico. Zoologia, 29: 227 - 276. DOI: 10.1590/S1984-46702012000300006

LAMOTHE-ARGUMEDO, R. 1997. [Manual for preparing and study parasites of wildlife animal hosts]. 1st edn. AGT Editor, Mexico City, 43 pp. (In Spanish)

Lamothe-Argumedo, R., García-Prieto, L., Osorio-Sarabia, D., Pérez-Ponce De León, G. (1997): [Catalogue of the helminths National Collection]. Mexico City: Universidad Nacional Autónoma de México, Instituto de Biología, CONABIO, 211 pp. (In Spanish)

Lester, R.J.G., MACKenzie, K. (2009): The use and abuse of parasites as stock markers for fish. Fish. Res., 97: 1 - 2. DOI: 10.1016/j.fishres.2008.12.016

Lo, C.M., Morand, S., GalzIN, R. (1998): Parasite diversitylhost age and size relationship in three coral-reef fishes from French Polynesia. Int. J. Parasitol., 28: 1695 - 1708. DOI: 10.1016/S00207519(98)00140-4

MACKENZIE, K. (2005): Parasites as biological tags. In: Rohde, K. (Ed.) Marine Parasitology. Collingwood, Australia: CSIRO Publishing, pp. $351-355$

MaguRRAn, A. (1988): Ecological diversity and its measurements. London, Chapman and Hall, 179 pp.

MARCOGLIESE, D.J. (2005): Parasites of the superorganism: are they indicators of ecosystem health? Int. J. Parasitol., 35: 705 - 716. DOI: 10.1016/j.jpara.2005.01.015

Montoya-Mendoza, J., Castañeda-Chávez, M.R., Lango-Reynoso, F., Rojas-CASTAÑEda, S. (2016): Helminth parasites of lane snapper, Lutjanus synagris from Santiaguillo Reef, Veracruz, Mexico. J. Agricult. Sci., 8: 81 - 88. DOI: 10.5539/jas.v8n11p81

Montoya-Mendoza, J., Jiménez-Badillo, L., Salgado-Maldonado, G., Mendoza-Franco, E.F. (2014): Helminth parasites of the red snapper, Lutjanus campechanus (Perciformes: Lutjanidae) from the reef Santiaguillo, Veracruz, Mexico. J. Parasitol., 100: 868 - 872. DOI: 10.1645/13-429.1

Moore, B.R., Stapley, J., Allsop, Q., Newman, S.J., Ballagh, A., WELCH, D.J. (2011): Stock structure of blue threadfin Eleutheronema tetradactylum across northern Australia, as indicated by parasites. J. Fish Biol., 78: 923 - 936. DOI: 1095-8649.2011.02917.x. Pérez-Ponce de León, G., García-Prieto, L., Mendoza-Garfias, B., León-Regagnon, V., Pulido-Flores, G., Aranda-Cruz, C., GARCIA-VARGAS, F. (1999): [Biodiversity of parasite helminths of marine and estuarine fishes from Chamela Bay, Jalisco]. Mexico City: Universidad Nacional Autónoma de México, Instituto de Biología, 51 pp. (In Spanish) 
Poulin, R. (2000): Variation in the intraspecific relationship between fish length and intensity of parasitic infection: biological and statistical causes. J. Fish Biol., 56: 123 - 137. DOI: 10.1111/j.10958649.2000.tb02090.x.

Poulin, R. (2003): The decay of similarity with geographical distance in parasite communities of vertebrate host. J. Biogeogr., 30: 1609 - 1615. DOI: 10.1046/j.1365-2699.2003.00949.x

Reiczigel, J., Rozsa, L., Reiczigel, A., Fabian, I. (2013): Quantitative parasitology (QPweb). Available from: http://www2.univet.hu/ qpweb

Rodríguez-Santiago, M.A., Rosales-Casián, J.A. (2011): Parasite structure of the ocean whitefish Caulolatilus princeps from Baja California, México (East Pacific). Helgoland Mar. Res., 65: 197 202. DOI: $10.1007 /$ s10152-010-0215-2

Rodríguez-Santiago, M.A., Rosales-Casián, J.A., Grano-MaldonaDO, M.I. (2014): Dynamics of a parasite assemblage of the vermilion rockfish Sebastes miniatus from northwestern Baja California, México. Helgoland Mar. Res., 68: 299 - 306. DOI: 10.1007/ s10152-014-0390-7

Rojas-Herrera, A.A., Mascaró, M., Chiapa-Carrara, X. (2004): [Feeding habits of the fishes Lutjanus peru and Lutjanus guttatus (Pisces: Lutjanidae) from Guerrero, Mexico]. Rev. Biol. Trop., 52: 959 - 971 (In Spanish)

Rozsa, L., Reiczigel, J., Majoros, G. (2000): Quantifying parasites in samples of hosts. J. Parasitol., 86: 228 - 232. DOI: 10.1645/0022-3395(2000)086[0228:QPISOH]2.0.CO;2
SoleR-JIMÉnEZ, L., FAJer-ÁvILA, E.J. (2012): Microhabitats of dactylogyrids monogenean on the gills of wild spotted rose snapper, Lutjanus guttatus (Steindachner, 1869) from Mazatlán Bay, México. Folia Parasitol., 59: 53 - 58. DOI: 10.14411/fp.2012.008

Soler-Jiménez, L., GarcíA-Gasca, A., Fajer-Ávila, E. (2012): Euryhaliotrematoides mehen $n$. sp. (Dactylogyridae) from the gills of the spotted rose snapper, Lutjanus guttatus (Lutjanidae; Perciformes). Syst. Parasitol., 82: 113 - 119. DOI: 10.1007/s11230-012-9351-1 Soler-Jiménez, L.C., Morales-Serna, F.N., Fajer-Ávila, E.J. (2015): Rapid infection and proliferation of dactylogyrid monogeneans on gills of spotted rose snapper (Lutjanus guttatus) after transfer to a sea-cage. Vet. Parasitol., 210: 186 - 193. DOI: 10.1016/j.vetpar.2015.04.005

TIMI, J.T., LUQUE, J.L., PouLIN, R. (2010): Host ontogeny and the temporal decay of similarity in parasite communities of marine fish. Int. J. Parasitol., 40: 963 - 968. DOI: 10.1016/j.jpara.2010.02.005 Van Der Heiden, A.M., Hendrickx M.E. (1982): [Inventory of marine and coastal fauna from southern Sinaloa, Mexico]. Universidad Nacional Autónoma de México, Instituto de Ciencias del Mar y Limnología, Estación Mazatlán, 135 pp. (In Spanish)

Violante-González, J., Gallegos-Navarro, Y., Monks, S., GarcíaIbañez, S., Rojas-Herrera, A.A., Pulido-Flores, G., Villerías-Salinas, S., Larumbe-Morán, E. (2016): Parasites of the Green Jack Caranx caballus (Pisces: Carangidae) in three locations from $\mathrm{Pa}$ cific coast of Mexico, and their utility as biological tags. Rev. Mex. Biodiv., 87: 1015 - 1022. DOI: 10.1016/j.rmb.2016.07.010 